\title{
Differential gene expression and mitotic cell analysis of the drought tolerant soybean (Glycine max L. Merrill Fabales, Fabaceae) cultivar MG/BR46 (Conquista) under two water deficit induction systems
}

\author{
Polyana K. Martins ${ }^{1}$, Berenice Q. Jordão ${ }^{2}$, Naoki Yamanaka ${ }^{3}$, José R.B. Farias ${ }^{4}$, Magda A. Beneventi ${ }^{1}$, \\ Eliseu Binneck ${ }^{4}$, Renata Fuganti ${ }^{1}$, Renata Stolf ${ }^{1}$ and Alexandre L. Nepomuceno ${ }^{4}$ \\ ${ }^{1}$ Programa de Pós-Graduação em Genética e Biologia Molecular, Universidade Estadual de Londrina, \\ Londrina, PR, Brazil. \\ ${ }^{2}$ Departamento de Biologia Geral, Universidade Estadual de Londrina, Londrina, PR, Brazil. \\ ${ }^{3}$ Japan International Research Center for Agricultural Science, Tsukuba, Japan. \\ ${ }^{4}$ Embrapa Soja, Londrina, PR, Brazil.
}

\begin{abstract}
Drought cause serious yield losses in soybean (Glycine max), roots being the first plant organ to detect the water-stress signals triggering defense mechanisms. We used two drought induction systems to identify genes differentially expressed in the roots of the drought-tolerant soybean cultivar MG/BR46 (Conquista) and characterize their expression levels during water deficit. Soybean plants grown in nutrient solution hydroponically and in sand-pots were submitted to water stress and gene expression analysis was conducted using the differential display (DD) and real time polymerase chain reaction (PCR) techniques. Three differentially expressed mRNA transcripts showed homology to the Antirrhinum majus basic helix-loop-helix transcription factor $b H L H$, the Arabidopsis thaliana phosphatidylinositol transfer protein PITP and the auxin-independent growth regulator 1 (axi 1). The hydroponic experiments showed that after 100 min outside the nutrient solution photosynthesis completely stopped, stomata closed and leaf temperature rose. Both stress induction treatments produced significant decrease in the mitotic indices of root cells. Axi 1, PITP and bHLH were not only differentially expressed during dehydration in the hydroponics experiments but also during induced drought in the pot experiments. Although, there were differences between the two sets of experiments in the time at which up or down regulation occurred, the expression pattern of all three transcripts was related. Similar gene expression and cytological analysis results occurred in both systems, suggesting that hydroponics could be used to simulate drought detection by roots growing in soil and thus facilitate rapid and easy root sampling.
\end{abstract}

Key words: cell division, differential display, gene expression, real time PCR, soybean, water stress.

Received: May 11, 2007; Accepted: November 8, 2007.

\section{Introduction}

Abiotic stresses such as drought can significantly reduce agricultural production, with harsh consequences for the producers and economies. A report from the Brazilian Ministry of Agriculture on cropping insurance (Göpfert et al., 1993) indicates drought as the main cause of crop failure, with $71 \%$ of the insurance claim cases. Southern Brazilian states, responsible for approximately $40 \%$ of Brazil's total soybean production, lost more than $25 \%$ of total production due to drought in the last two years, with producers having lost more than U\$2.32 million in 2004/2005 (unpublished data).

Send correspondence to Alexandre L. Nepomuceno. Embrapa Soybean, Rodovia Carlos Strass, Distrito da Warta, Caixa Postal 6001, 86001-970 Londrina, PR, Brazil. E-mail: nepo@cnpso.embrapa.br.
The nutritional value and the economic importance of soybean (Glycine max L. Merrill) have stimulated the increase in its global cultivation during recent decades. Breeding for adaptation to water-deficient conditions is a good option to reduce losses in productivity due to drought. However, it is important to identify parameters that will allow the rapid and efficient evaluation of the capacity of plants to tolerate moisture deficiency (Casagrande et al., 2001). This goal is not easy to achieve considering the complexity and the amount of genes involved in drought defense mechanisms (Yamaguchi-Shinozaki et al., 2002). Thus, it is important to develop an understanding of how plants respond to water deficit at the molecular, cellular and physiological level (Bray, 2004; Shinozaki. and Yamaguchi-Shinozaki, 2007). 
Each specific response to water deficit is a result of previous molecular events that were activated by stress. For example, changes in the volume of individual cells in roots or other organs submitted to water deficit can activate channels in the cellular membrane, can cause alterations in the conformation and position of membrane proteins responsible for stress detection or can induce alterations in the cell wall/cell membrane continuum (Har and Cress 1996). Many of these modifications activate enzymatic complexes that trigger a cascade of molecular events leading to the expression of various categories of genes (Shinozaki and Yamaguchi-Shinozaki, 1997, 1999; Shinozaki et al., 2003; Zhang et al., 2004).

When water is lost in cells, regulatory processes are triggered to adjust the metabolism to this new condition. Simultaneously, growth is inhibited and alterations in development result in other changes in gene expression. The expression of genes involved in the control of cell proliferation, such as cyclins and cyclin-dependent kinases (CDKs), may be modified. Genes regulated in metabolism, signal recognition and signal transduction pathways are also modulated under stress (Har and Cress, 1996; Bray, 2004).

The expression of genes in soybean water-deficittolerant genotypes can be used to study drought tolerance mechanisms and in the identification of other genotypes with similar characteristics. The identification and understanding of tolerance mechanisms is crucial not only in soybean but also in other crops (Somerville and Koornneef, 2002; Nepomuceno et al., 2002). Since roots play a key role in stress detection and tolerance response, a reliable system for molecular analysis in roots should be used to ensure consistency among studies.

The objectives of this work described in this paper were to identify genes differentially expressed in the roots of the drought-tolerant soybean cultivar Conquista (MG/BR46), to characterize the expression levels of these genes in this cultivar during water deficit under two drought induction systems and propose a fast and reliable method to simulate drought induction in roots used in molecular studies.

\section{Materials and Methods}

\section{Plants and treatments}

We used Glycine max L. Merrill cultivar MG/BR46 (Conquista) as the drought-tolerant standard based on preliminary greenhouse experiments and field studies (Casagrande et al., 2001) and also on empirical observations made by breeders and producers indicating that this cultivar has a high capacity in tolerating periods of water deficiency.

We used two different water deficit treatments, a hydroponics system in which plants were grown in a nutrient solution (Hewitt, 1963) and a pot-based system in which plants were grown in sand contained in polyvinyl chloride
(PVC) pots irrigated with the same nutrient solution as was used in the hydroponic system. In both systems, samples were taken when the plants were at similar developmental vegetative stages.

In the hydroponics system plants were grown in eight plastic containers $(30 \mathrm{~L})$ an aerated $\mathrm{pH} 6.6$ balanced nutrient solution (Hewitt, 1963). Seeds were pre-germinated on moist filter paper in the dark at $25^{\circ} \mathrm{C} \pm 1{ }^{\circ} \mathrm{C}$ and $65 \% \pm 5 \%$ of temperature and relative humidity, respectively. Then plantlets were placed in wood supports in such a way that the roots of the seedlings were completely immersed in the solution. Each tray containing 15 seedlings and was maintained in a greenhouse at $25^{\circ} \mathrm{C} \pm 2{ }^{\circ} \mathrm{C}$ and $60 \% \pm 5 \%$ of temperature and relative humidity, respectively, under natural daylight (photosynthetic photon flux density (PPFD) = $1.5 \times 10^{3} \mu$ moles $\mathrm{m}^{-2} \mathrm{~s}^{-1}$, equivalent to $8.93 \times 10^{4} \mathrm{lux}$ ) and a $12 \mathrm{~h}$ day length. After 15 days seedlings were submitted to different treatments in which they were removed from the hydroponic solution and kept in a tray in the dark without nutrient solution or water for $0 \mathrm{~min}$ (control), $50 \mathrm{~min}$, $100 \mathrm{~min}$ and $150 \mathrm{~min}, 15$ seedlings being used per treatment. The different times were based on our unpublished data for photosynthesis which showed that soybean seedlings showed maximum photosynthesis at time zero and maximum respiration $150 \mathrm{~min}$ after being subjected to water stress.

In the pot-based system seeds were sown in PVC pots containing washed sand and kept in a greenhouse under the same conditions as described above. The volume of MilliQ water added was adjusted to keep the plants in the pots at $15 \%$ gravimetric humidity $(\mathrm{GH})$ for the unstressed treatment and 5\% GH for the stressed treatment, 10 plants being used per treatment. The GH was calculated as the percentage of water in the sand in relation to the dry weight of the sand (Lehane and Staple, 1965). These percentages were chosen based on unpublished data from preliminary experiments in which 5\% GH promoted a moderate water deficit and $15 \% \mathrm{GH}$ kept the sand in the pots close to field capacity. The pots were irrigated twice a week with $\mathrm{pH} 6.6$ balanced nutrient solution (Hewitt, 1963) and kept at 15\% GH for 30 days post-sowing, after which irrigation was withheld from the stress-treatment pots until the $\mathrm{GH}$ values reached 5\%. Pots were weight twice a day and water added as needed to maintain the desired GH values. Root samples were collected in all treatments 30 days post-sowing, 45 days post-sowing ( 15 days after the beginning of the stress treatment) and 60 days post-sowing ( 30 days after the beginning of the stress treatment).

\section{Physiological and cytological analysis}

Net photosynthesis, stomatal conductance and leaf temperature were measured using a Model LI-6400 Portable Photosynthesis System, (LI-COR, Inc., Nebraska, US) in periods of $0 \mathrm{~min}, 25 \mathrm{~min}, 50 \mathrm{~min}, 75 \mathrm{~min}, 100 \mathrm{~min}$, $125 \mathrm{~min}, 150 \mathrm{~min}$ of dehydration. For all treatments mea- 
surements were made on the third leaf from the top of the main stems of all the plants growing in the greenhouse at $25^{\circ} \mathrm{C} \pm 2{ }^{\circ} \mathrm{C}$ and $60 \% \pm 5 \%$ of temperature and relative humidity, respectively. Photosynthetic photon flux density (PPFD) was about $1.500 \mu$ moles $\mathrm{m}^{-2} \mathrm{~s}^{-1}$ during measurements.

For cellular proliferation analyses of roots from both systems we collected the first $2 \mathrm{~cm}$ of root tips, although only $2 \mathrm{~mm}$ were used to prepare the slides. The samples were fixed in ethanol $(95 \% \mathrm{v} / \mathrm{v})$ :chloroform:propionic acid $(6: 3: 2, \mathrm{v} / \mathrm{v} / \mathrm{v})$ and cytologically examined using the squash technique after re-hydration and staining with $2 \%$ acetic orcein stain (Sigma). A total of 1,000 meristematic cells were scored on each slide and 10 slides (one from each seedling or plant) were analyzed per treatment for both systems. Cells in interphase and other phases of mitosis were quantified and the Mitosis index (MI) and Mitotic phase index (MPI) we calculated as MI = Total number of cells in mitosis 100/ Total number of meristematic cells and MPI = Total number of cells in a particular mitotic phase 100 / Total number of cells in mitosis. Analysis of variance was performed on the data and the significance of differences between means was determined by the Tukey test $(\mathrm{p} \leq 0.05)$.

\section{Reverse Transcription (RT) and Differential Display (DD) gene expression analysis}

For gene expression analysis of the seedlings or plants in each system and treatment we excised $5 \mathrm{~cm}$ of young root tip tissue starting at the meristematic tip and extending to the mature part of the root, the material collected being stored in a freezer at $-80^{\circ} \mathrm{C}$ until RNA extraction.

For each treatment, roots were excised and total RNA was isolated by extraction with Trizol (Invitrogen) and mRNA was extracted using the Message Maker Kit (Invitrogen). All samples were submitted to agarose gel electrophoresis to check RNA quality.

The mRNA from each seedling or plant was first subjected to reverse transcription (RT) and then to the differential display polymerase chain reaction (DD-PCR) and real time PCR. Reverse transcription was carried out in a final reaction volume of $50 \mu \mathrm{L}$ containing $5 \mu \mathrm{L}$ sample mRNA $\left(0.5 \mu \mathrm{g} \mu \mathrm{L}^{-1}\right), 10 \mu \mathrm{L} 5 \mathrm{X}$ buffer [250 mM Tris-HCL (pH 8.3), $375 \mathrm{mM} \mathrm{KCL}, 15 \mathrm{mM} \mathrm{MgCL} 2], 1.5 \mu \mathrm{L}$ dNTP (10 mM), $31 \mu \mathrm{L}$ of water containing $0.1 \%(\mathrm{w} / \mathrm{v})$ of the ribonuclease inhibitor diethylpyrocarbonate (DEPC Sigma), $1.5 \mu \mathrm{L}$ of M-MVL reverse transcriptase (Invitrogen) and $2.5 \mu \mathrm{L}$ of a solution containing $50 \mu \mathrm{M}$ each of anchor primers A1 $\left(5^{\prime} \mathrm{T}_{(9)} \mathrm{GC}^{\prime}\right), \quad$ A2 $\quad\left(5^{\prime} \mathrm{T}_{(9)} \mathrm{CC} 3{ }^{\prime}\right), \quad$ A3 $\left(5^{\prime} \mathrm{T}_{(9)} \mathrm{GG} 3^{\prime}\right)$ and $\mathrm{A} 4\left(5^{\prime} \mathrm{T}_{(9)} \mathrm{CG} 3\right.$ '). The anchor primers were purchased from Invitrogen and chosen because they showed higher polymorphism in pilot testing (data not shown). The RT mixture was incubated at $37^{\circ} \mathrm{C}$ for $1 \mathrm{~h}$, and then at $99{ }^{\circ} \mathrm{C}$ for $5 \mathrm{~min}$.

Differential display PCR was carried out in a final volume of $25 \mu \mathrm{L}$ containing $4 \mu \mathrm{L}$ of the reacted RT mixture, $6.25 \mu \mathrm{L}$ of dNTP mixture $(100 \mu \mathrm{M}), 2.5 \mu \mathrm{L}$ of $10 \mathrm{X}$ Taq buffer, $1.25 \mu \mathrm{L}$ of $50 \mathrm{mM} \mathrm{MgCl} 2,1 \mu \mathrm{L}$ of anchor primer (50 $\mu \mathrm{M}), 0.5 \mu \mathrm{L}$ of $5 \mathrm{U}^{-1}$ Taq DNA polymerase (Invitrogen), $8.7 \mu \mathrm{L}$ water containing $0.1 \%(\mathrm{w} / \mathrm{v}) \mathrm{DEPC}$, $0.3 \mu \mathrm{L}$ of $10 \mathrm{mCi} \mathrm{mL}^{-1}\left(2.510^{3} \mathrm{Ci} \mathrm{mmol}^{-1}\left[\alpha-{ }^{33} \mathrm{P}\right] \mathrm{dATP}\right.$ (Amersham Biosciences) and $0.5 \mu \mathrm{L}$ of a solution containing $50 \mu \mathrm{M}$ each of the random primers B2 (5'GTGCGTC CTC3 '), B3 (5'AAGCTGCGAG3'), B5 (5'TGGACGCG AG3'), B7 (5'CCGTCACTGG3'), B8 (5'CCCTCACTG G3') and B9 (5'GCGAAACGCG3') purchased from Invitrogen.

Amplification was initially at $94{ }^{\circ} \mathrm{C}$ for $2 \mathrm{~min}$, followed by forty cycles of $94{ }^{\circ} \mathrm{C}$ for $30 \mathrm{~s}, 42{ }^{\circ} \mathrm{C}$ for $1 \mathrm{~min}$ and $72{ }^{\circ} \mathrm{C}$ for $30 \mathrm{~s}$. The PCR products were separated from $7 \mu \mathrm{L}$ of the PCR reaction product mixture by electrophoresis on $6 \%(\mathrm{w} / \mathrm{v})$ polyacrylamide at $75 \mathrm{~W}$ for $4 \mathrm{~h}$. After electrophoresis gels were dried at $80{ }^{\circ} \mathrm{C}$ for $2.5 \mathrm{~h}$ and bands detected by autoradiography for $72 \mathrm{~h}$ using Kodak autoradiography film.

Differentially expressed bands were extracted from the gel, purified and re-amplified using PCR according to Song et al. (1995) and Nepomuceno et al. (1998). The re-amplified fragments were cloned in the pGEM-T vector using the Easy Vector System I (Promega). Clones were sequenced by thermal cycling with the ABI Prism BigDye Terminator Cycle Sequencing Kit v2.0 and ABI 3100 automatic sequencer (Applied Biosystems). The BlastX2 program was used to search GenBank for similarities between the clones and known genes.

\section{Ribonuclease protection assay (RPA) gene expression analysis}

The fragments of three clones (A2B3-2, A2B8-6 and A4B3-10) were used to synthesized ${ }^{32} \mathrm{P}$-labeled anti-sense RNA probes (Amersham, USA) complementary to the region of the target RNA to be analyzed. The clones were coded as follows: First Letter + number $=$ anchor primer; Second Letter + number $=10$-mer primer; and third number $=$ band position in the gel. Complete runoffs of the transcripts representing the insert anti-sense strand were produced using T7 or SP6 RNA polymerase (Ambion, USA). The anti-sense riboprobes were produced using a MAXIscrip Kit (Ambion, USA). The RPA reactions were performed using a HybSpeed RPA Kit (Ambion, USA). After hybridized, the complementary mRNA present in the total RNA extracted and the labeled anti-sense probes, were protected from ribonuclease digestion. These complex probe-complementary mRNAs were separated on $5 \%(\mathrm{w} / \mathrm{v})$ polyacrylamide gel and visualized by autoradiography using Kodak autoradiography film. 


\section{Real time PCR (RT-PCR) gene expression analysis}

The procedure used to obtain complementary DNA (cDNA) for the RT-PCR was the same as that described for the DD reactions, except that we used oligo-dT primers (Invitrogen) instead of anchored primers in the reverse transcription reaction. Real-time PCR was performed with an ABI Prism 7300 Real Time PCR system using the SYBR Green PCR master mix kit (Invitrogen).

Primers for specific amplification of each cDNA were designed using the Primer Express software (Applied Biosystems), taking into account criteria such as product length, optimal PCR annealing temperature and the likelihood of primer self-annealing. The following primers were used for the different clones: A2B3-2 $=5^{\prime}$ CAAATCTATG TGTGCTGGTAGG3' and 5'GGAACAAGCCAAGTCA AGAAA3'; A2B8-6 = 5'CACATTGATTCCAGCACCA C3' and 5'AATCCAGGCCCAGCATTTAT3'; and A4B3-10 5'CCATGCAGCCTCTCAAAGAT3' and 5' 3'AAGGATTTTGGCCATGTTACC3'. The PCR reactions were carried out in technical triplicates in a $25 \mu \mathrm{L}$ final volume using $500 \mathrm{nM}$ each of forward and reverse primers, $12.5 \mu \mathrm{L}$ of SYBR green master mix (Applied Biosystems), $5 \mu \mathrm{L}$ of a 1:10 (v/v) dilution of cDNA and $25 \mu \mathrm{L}$ MilliQ water (MilliQ). Reactions were performed in MicroAmp 96-well plates (Applied Biosystems) covered with optical adhesive (Applied Biosystems). Samples were submitted to forty cycles of $95^{\circ} \mathrm{C}$ for $15 \mathrm{~s}, 60^{\circ} \mathrm{C}$ for $30 \mathrm{~s}$ and $72{ }^{\circ} \mathrm{C}$ for $1 \mathrm{~min}$. An amplification efficiency curve us- ing four different cDNA dilutions (1, 0.1, 0.01 and 0.001$)$ was also made for each gene tested.

All statistical analysis were performed as described in the ABI 7300 sequence detection system User Bulletin (Applied Biosystems) using the Relative Quantification module.

For the RNA samples reactions using the A2B3-2, A2B8-6 and A4B3-10 clones were normalized at the transcription level using the expression levels of $18 \mathrm{~S}$ rRNA as an internal control. For relative comparison we used material collected at the start of the experiment (time $=0 \mathrm{~min}$ ) for the hydroponic experiments while for the pot experiments we used material from the $15 \% \mathrm{GH}$ treatments 30 days after treatment started, both sets of material being used as calibrators in which $1 \mathrm{x}=1$ fold expression.

To verify nonspecific PCR products and primer dimers a melting curve was performed immediately after amplification by using the ABI PRISM Dissociation Analysis software (Applied Biosystems).

\section{Results}

The analysis of cellular proliferation showed that drought stress induced significant decreases in the mitotic indices of root tissue in both the hydroponic and pot experiments (Table 1). Both water-deficit induction methods seemed to produce similar rates in terms of reduction of cellular proliferation during cell dehydration. Although, the time course for cellular division events were

Table 1 - Root cell proliferation indices for the drought tolerant soybean cultivar MG/BR46 growing in hydroponic and pot cultivation systems under different levels of water stress. For hydroponic cultivation the plants were stressed by removing them from the nutrient solution for the stated time, the roots of the unstressed controls being sampled immediately upon removal. For pot cultivation the plants were grown in sand supplemented with the same nutrient solution as was used in the hydroponic cultivation, the unstressed plants being grown for the stated times at a gravimetric humidity (GH) of $15 \%$ for the unstressed plants and 5\% for the stressed plants. In the pot cultivation system, for the unstressed control, roots were collected 30 days post-sowing, while for the stress treatments roots were collected 45 days post-sowing ( 15 days after the beginning of the stress treatment) and 60 days post-sowing ( 30 days after the beginning of the stress treatment).

\begin{tabular}{lccccc}
\hline & \multicolumn{3}{c}{ Root cell proliferation indices (means)* } \\
\cline { 2 - 6 } Cultivation system and treatments & Mitosis index & Prophase index & Metaphase index & Anaphase index & Telophase index \\
\hline Hydroponic cultivation† & & & & & \\
Unstressed controls, 0 min & $17.74 \mathrm{a}$ & $64.56 \mathrm{a}$ & $8.32 \mathrm{a}$ & $4.67 \mathrm{a}$ & $22.43 \mathrm{c}$ \\
Stressed, for 50 min & $5.65 \mathrm{~b}$ & $27.83 \mathrm{bc}$ & $9.19 \mathrm{a}$ & $2.59 \mathrm{~b}$ & $60.37 \mathrm{~b}$ \\
Stressed for 100 min & $5.50 \mathrm{~b}$ & $26.29 \mathrm{c}$ & $2.87 \mathrm{~b}$ & $1.12 \mathrm{~b}$ & $69.71 \mathrm{a}$ \\
Stressed for 150 min & $3.90 \mathrm{c}$ & $30.13 \mathrm{~b}$ & $2.67 \mathrm{~b}$ & $0.73 \mathrm{~b}$ & $66.45 \mathrm{a}$ \\
\hline Pots (sand) cultivation†t & & & & & \\
Unstressed controls, 30 days post-sowing & $16.3 \mathrm{a}$ & $67.87 \mathrm{a}$ & $7.89 \mathrm{c}$ & $3.63 \mathrm{c}$ & $20.60 \mathrm{c}$ \\
Unstressed, 45 days post-sowing & $14.39 \mathrm{bA}$ & $60.01 \mathrm{bA}$ & $10.17 \mathrm{bB}$ & $5.76 \mathrm{bB}$ & $24.04 \mathrm{bB}$ \\
Unstressed, 60 days post-sowing & $14.57 \mathrm{bA}$ & $48.10 \mathrm{cA}$ & $13.53 \mathrm{aB}$ & $7.55 \mathrm{aA}$ & $30.81 \mathrm{aB}$ \\
Stressed, 45 days post-sowing & $11.97 \mathrm{aB}$ & $41.42 \mathrm{aB}$ & $13.21 \mathrm{bA}$ & $6.86 \mathrm{aA}$ & $38.48 \mathrm{bA}$ \\
Stressed, 60 days post-sowing & $9.57 \mathrm{bB}$ & $33.67 \mathrm{bB}$ & $20.13 \mathrm{aA}$ & $6.61 \mathrm{aA}$ & $39.57 \mathrm{aA}$ \\
\hline
\end{tabular}

$\dagger$ Means with the same lowercase letters were not significantly different by the Tukey test at $\mathrm{p} \leq 0.05$.

$\$$ For the same time of stress treatment (unstressed 45 days stressed 45 days, unstressed 60 days stressed 60 days) means with the same uppercase letters were not significantly different by the Tukey test at $\mathrm{p} \leq 0.05$. 
different when comparing the two experiments, the analysis indicated that, under stress, roots in both experiments reduced the number of cells in mitosis, prophase, metaphase and anaphase during dehydration. These reductions were more severe in the hydroponic experiments than in the pot experiments.

In the hydroponic experiments net photosynthesis, stomatal conductance and leaf temperature (Figure 1) during dehydration showed a rapid onset of negative drought effects, with the seedlings showing no photosynthesis, closed stomata and increased leaf temperature after 100 min outside the nutrient solution.

The gene analysis results allowed the identification of three differential expressed DD fragments (Figure 2). The RPA results confirmed the expression of all the differentially expressed transcripts (Figure 3).

Searches in the GenBank database (www.ncbi.nlm. nih.gov), using the BlastX program, showed that these fragments have homology with known genes that might be related to molecular responses to cell dehydration. Clone A2B3-2 (EW678711) generated a 518-bp fragment differentially expressed in the hydroponic experiments only in the $100 \mathrm{~min}$ stress treatment (Table 2). This fragment showed homology to the basic helix-loop-helix transcription factor gene bHLH of Antirrhinum majus. The RT-PCR experiments revealed that in the hydroponic experiments the highest expression level of clone A2B3-2 was at $100 \mathrm{~min}$, after which the expression of this clone decreased (Figure 4). The same analysis was conducted with roots growing in pots under a stress of $5 \% \mathrm{GH}$ and after 15 days of stress (45 days post sowing). It was possible to show that the putative transcription factor A2B3-2 was also up regulated (Figure 4). Thus both stress inducing systems allowed identification of differences in expression levels of clone A2B3-2, although the time frame was different.

Clone A2B8-6 (EW678712) generated a 421-bp fragment, differentially expressed in the unstressed treatment (Figure 2), which showed homology to the phosphatidylinositol-transfer protein gene PITP from Arabidopsis thaliana (Table 2). Real time PCR analyses showed that both stress induction systems promoted down regulation of clone A2B8-6 during stress treatments (Figure 4). Reduction in PITP expression was observed in roots stressed in pots after 15 days at 5\% GH (Figure 4), while in the hydroponic experiments PITP expression was five times lower at $100 \mathrm{~min}$ and 16 times lower at $150 \mathrm{~min}$ after stress induction when compared to unstressed conditions (Figure 4).

Clone A4B3-10 (EW678713) generated a 497-bp fragment (Figure 2) which showed 90\% amino acid homology to the auxin-independent growth regulator 1 (axi 1) gene (Table 2) and was differentially expressed in the unstressed treatment, indicating normal root growth.

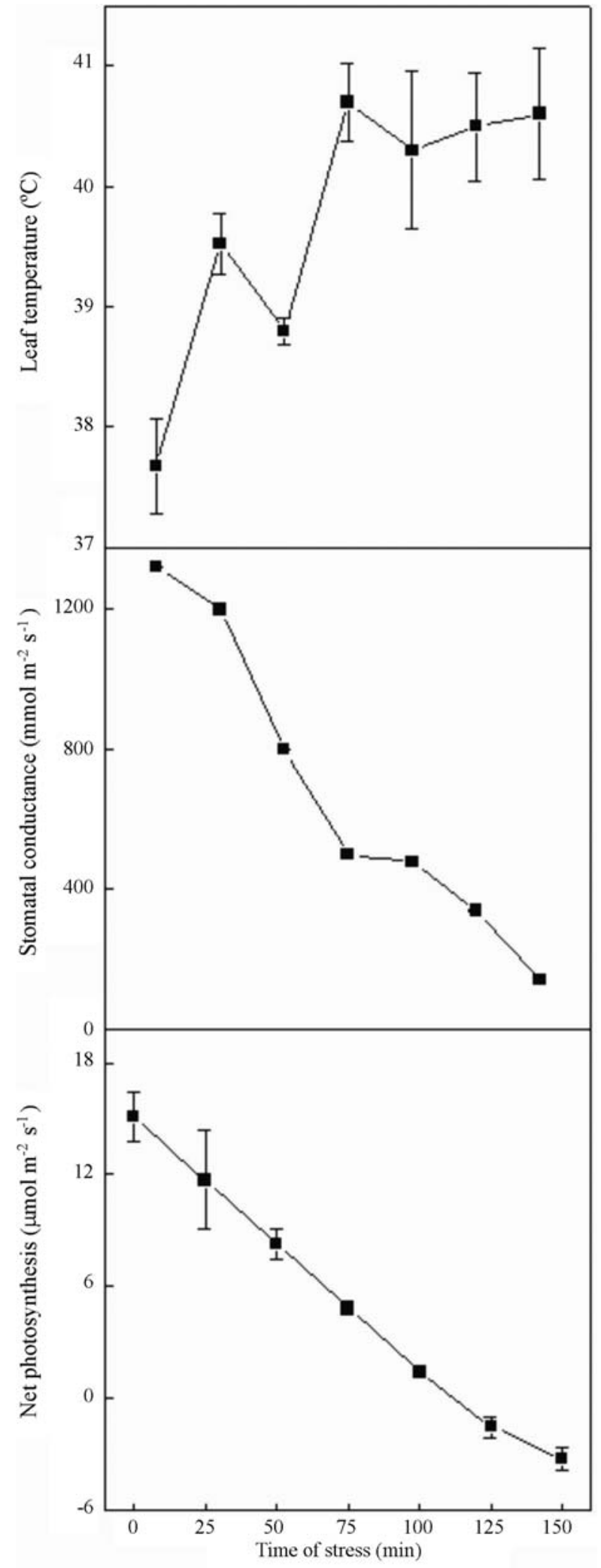

Figure 1 - Leaf temperature (a), stomatal conductance (b) and net photosynthesis (c) of tolerant soybean cultivar MG/BR46 submitted to hydroponic cultivation and dehydration periods of $0 \mathrm{~min}, 25 \mathrm{~min}, 50 \mathrm{~min}$, $75 \mathrm{~min}, 100 \mathrm{~min}, 125 \mathrm{~min}, 150 \mathrm{~min}$. When the standard error bars of the means do not coincide there is significant difference between means (Tukey test, $\mathrm{p} \leq 0.05$ ). 


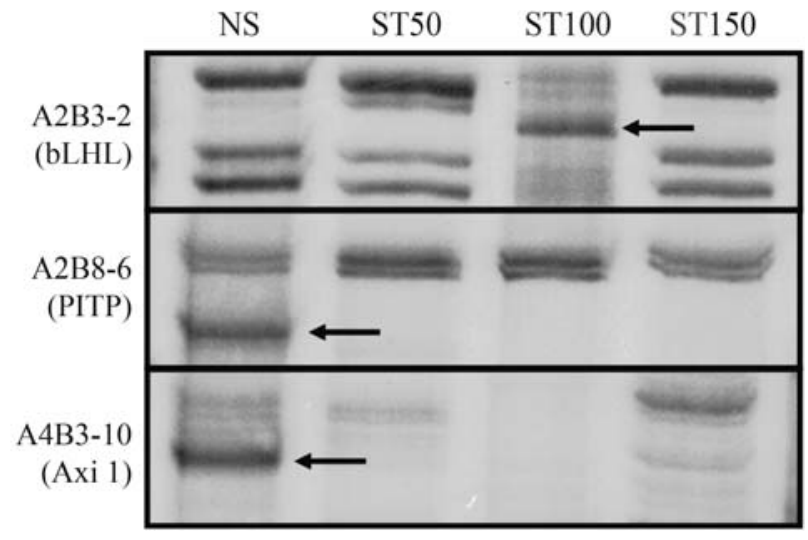

Figure 2 - Autoradiography showing the results of differential display done with drought-tolerant soybean cultivar MG/BR46 submitted to the Non-Stressed treatment (NS) and at water-deficiency stress treatments of $50 \mathrm{~min}, 100 \mathrm{~min}, 150 \mathrm{~min}$. Arrows indicate three bands (clones) that were differentially expressed in different treatments. Clone A2B3-2 was expressed after $100 \mathrm{~min}$ of water-deficiency stress and showed homology to the Antirrhinum majus basic helix-loop-helix transcription factor gene $b H L H$. The other two clones were expressed in the unstressed control treatment, the clones being clone A2B8-6, which showed homology to the phosphatidylinositol-transfer protein gene PITP from Arabidopsis thaliana, and clone A4B3-10, which showed $90 \%$ amino acid identity to the auxin independent growth regulator gene axi 1 .

\section{Discussion}

Plant responses to moisture deficiency are complex, with every phenotypic expression in plants exposed to water deficit being related to gene expression and environmental interactions. Tolerance can be conferred by hundreds of expressed genes in a precise arrangement or by just one gene which plays a key role in a specific metabolic pathway (Amtmann et al., 2005). The molecular, physiological and morphological traits of roots play a key role in drought tolerance.

Results from physiological characterization showed that drought affects seriously photosynthesis leading to stomata closure and increasing in leaf temperature. Cell dehydration and high leaf temperatures change the electron partitioning among respiratory pathways and therefore decrease the rate of mitochondrial ATP synthesis. The decline in leaf ATP concentration during water stress is considered a major factor limiting photosynthesis under water stress (Flexas et al., 2004; Ribas-Carbo et al., 2005). After complete disruption of photosynthesis systems, plants no longer are able to use their adaptive responses. Thus, before shutting down photosynthesis, multiple stress perception and signaling pathways, some of which are specific and others cross-talk are activated initiating adaptive responses that are critical in determining plants responses to mild or severe stresses at adverse environments (Chinnusamy et al., 2004). The time frame between stress recognition and the final adaptive response will differ according to severity of the stress. In the soil (or sand), roots suffering dehydration

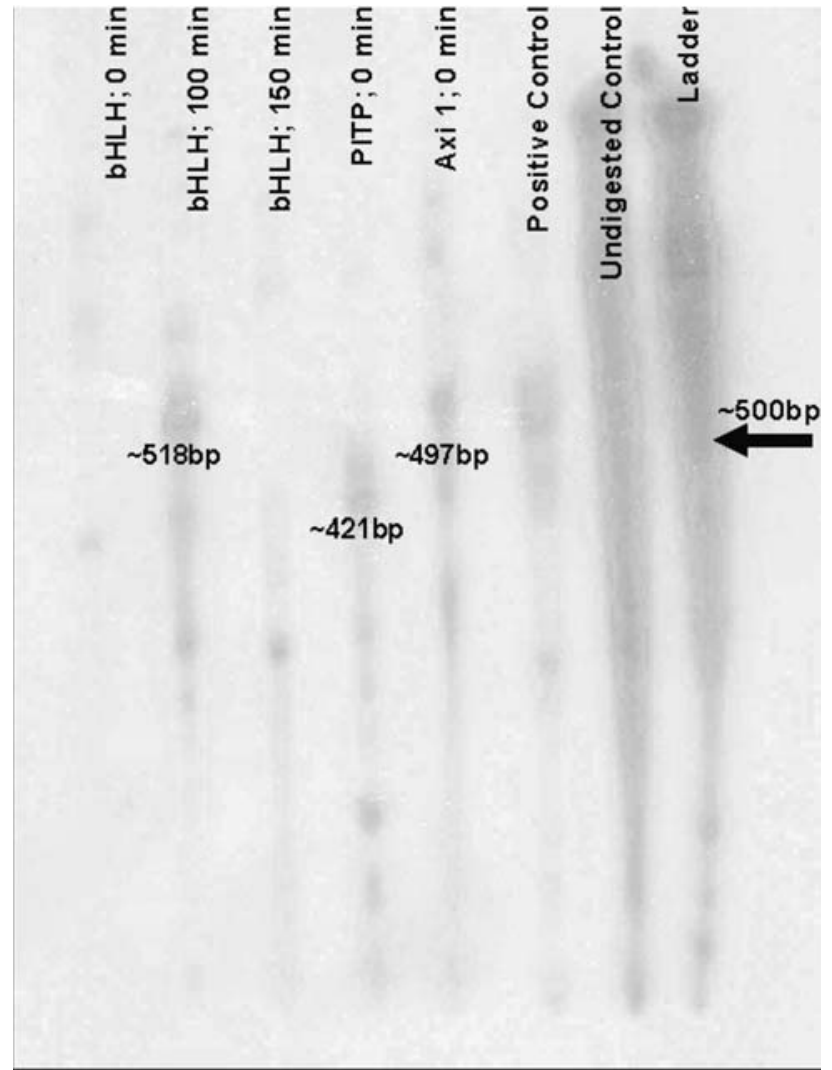

Figure 3 - Ribonuclease protection assay (RPA) radiograph showing the expression of the all differentially expressed transcripts genes (clones) identified in the various treatments by reverse transcription and differential display (DD) gene expression analysis. The $518 \mathrm{bp}$ fragment showed homology to the Antirrhinum majus basic helix-loop-helix transcription factor gene $b H L H$, the $421 \mathrm{bp}$ fragment showed homology to the Arabidopsis thaliana phosphatidylinositol-transfer protein gene PITP and the $497 \mathrm{bp}$ fragment showed $90 \%$ amino acid homology with the auxin independent growth regulator gene axi 1 . The positive control of the kit was also performed and an undigested control was used to check the Rnase activity. Ladder 500 bp.

will initiate defense responses slower than roots submitted to an environment completely without water. However, the stress recognition mechanisms involved in these responses should be the same, but expressed differently in time.

The mechanisms involved in drought defense responses begin at the molecular level, repressing or activating the transcription of specific genes. Transcription factors, such as clone A2B3-2, a putative basic helix-loophelix (bHLH), usually are necessary elements to start transcription. Plant bHLH proteins are a multigene family of transcription factors, with more than $100 \mathrm{bHLH}$ genes having been identified in the rice (Oryza sativa) and Arabidopsis thaliana genome (Kiribuchi et al., 2005). Some transcription factors are proteins that are expressed during specific developmental situations or only in specific tissues of the organism (Dey and Harborne, 1997; Lewin, 2000) but many transcription factors have also been identified which control the first steps of gene expression in metabolic pathways and where the signal transduction is 

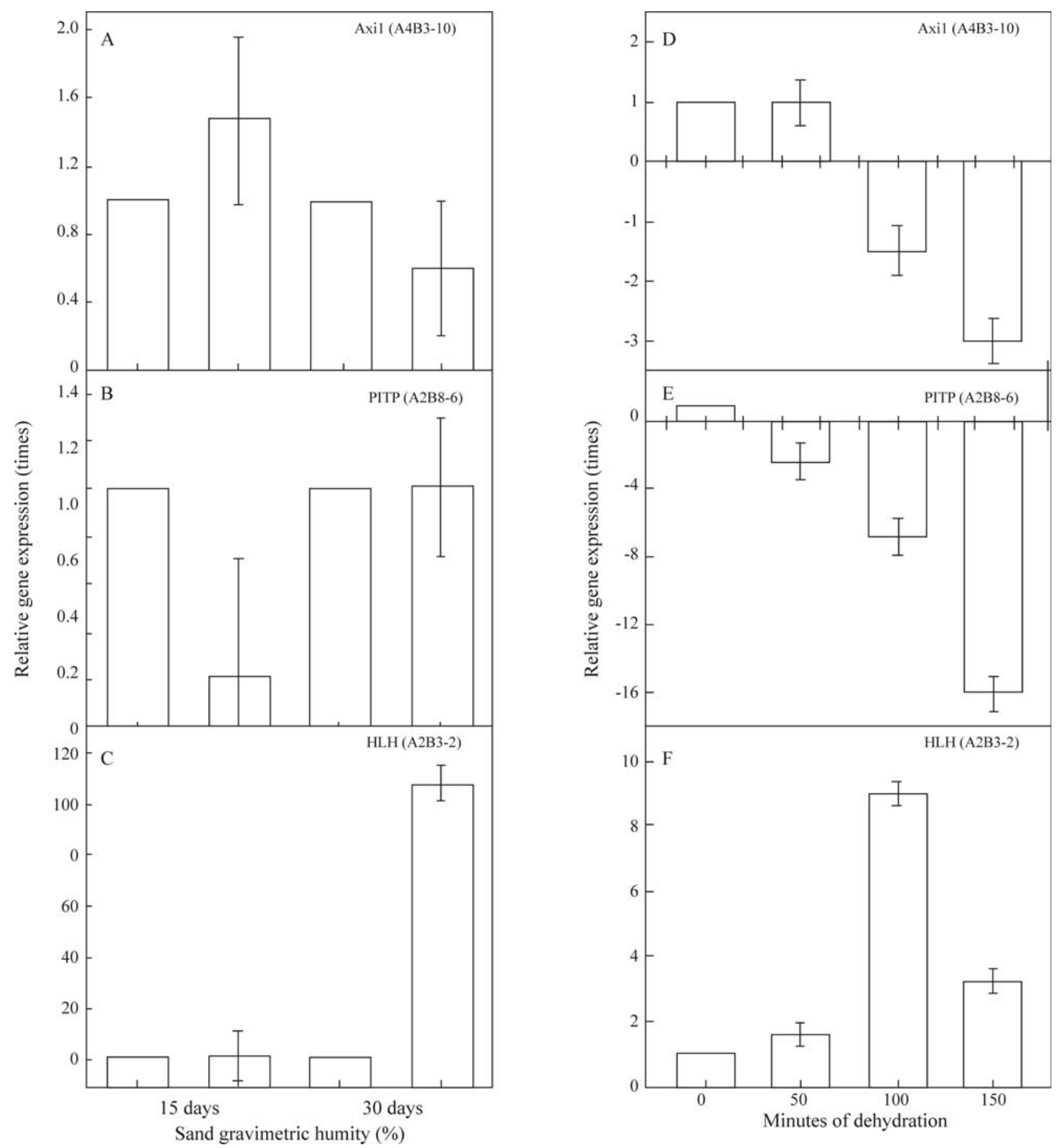

Figure 4 - Real time PCR results comparing the expression of clones A2B3-2, A2B8-6 and A4B3-10 in the roots of soybean cultivar MG/BR46 submitted to two water deficit induction systems. The left column represents the genes expressed in the pot experiments (unstressed $=15 \%$ gravimetric humidity $(\mathrm{GH})$, stressed $=5 \% \mathrm{GH})$ using sand as substrate and the right column represents the genes expressed in the hydroponics cultivations were the unstressed plants were kept in nutrient solution and the stressed plants were placed in a tray without solution in the dark for $50 \mathrm{~min}, 100 \mathrm{~min}$ and $150 \mathrm{~min}$. Normalization of the PCR was achieved by reference to the expression levels of an $18 \mathrm{~S} \mathrm{rRNA}$ internal control. The $15 \% \mathrm{GH}$ treatment was used as the 1-fold reference for the pot experiments while the 0 min treatment was used as the 1 -fold reference for the hydroponic experiments.

triggered by a stress (Chen et al., 2002). By altering the levels of expression of certain transcription factors it should be possible to modify plant tolerance to stress (Jaglo-Ottosen et al., 1998; Kasuga et al., 1999; Shinozaki. and Yamaguchi-Shinozaki, 2007).
According to the literature, the phosphatidylinositoltransfer proteins (PITP), like the one which showed homology with clone A2B8-6, are defined by their ability to transfer phosphatidylinositol (PtdIns) or phosphatidylcholine (PtdCho) monomers between membrane bilayers in vi- 
Table 2 - Three clones (putative genes) isolated from soybean root tissue using reverse transcription and differential display (DD) gene expression analysis. The soybean plantlets were subjected to four drought treatments while growing in nutrient solution in a hydroponic system. The clone identification code was as follows: first letter + number $=$ anchor primer; second letter + number $=10$-mer primer; and third number $=$ band position in the gel.

\begin{tabular}{|c|c|c|c|c|c|c|}
\hline \multirow{2}{*}{$\begin{array}{l}\text { Clone identification code } \\
\text { (accession number) }\end{array}$} & \multicolumn{6}{|c|}{ Drought treatment $\dagger$} \\
\hline & $\begin{array}{l}\text { Unstressed } \\
\text { (0 min) }\end{array}$ & $\begin{array}{l}\text { Stressed } \\
50 \mathrm{~min}\end{array}$ & $\begin{array}{l}\text { Stressed } \\
100 \mathrm{~min}\end{array}$ & $\begin{array}{l}\text { Stressed } \\
150 \mathrm{~min}\end{array}$ & $\begin{array}{l}\text { GenBank sequence with } \\
\text { high similarity }\end{array}$ & $\begin{array}{c}\text { Probability } \\
\text { (N) }\end{array}$ \\
\hline A2B3-2 (EW678711) & - & - & + & - & Helix-loop-helix transcription factor & $4.10^{-07}$ \\
\hline A2B8-6 (EW678712) & + & - & - & - & Phosphatidylinositol transfer protein & $8.10^{-58}$ \\
\hline A4B3-10 (EW678713) & + & - & - & - & Growth regulator gene axil & $5.10^{-62}$ \\
\hline
\end{tabular}

$\dagger$ Band present + , band absent -.

tro (Cleves et al., 1991; Wirtz, 1991). This type of protein modulates signal-transduction pathways and the transmission of molecular signals as well as functions related to the traffic of molecules across the plasma membrane (Kapranov et al., 2001). The activity of these proteins is related to the normal processes of cellular development such as the perception of diurnal cycles, cell division and stomata control. However, under dehydration many authors suggest that the lowering of turgor caused by water loss causes conformational changes in membrane sensory proteins, altering linkage of hormones (produced in other dehydrated cells) and also altering functionality of transfer proteins such as PITP. Changes in cytsolic $\mathrm{Ca}^{2+}$ level can activate many response genes to drought (Kim et al., 2004; Har et al., 1996). Studies in higher plants have produced evidence that variations in cytosolic $\mathrm{Ca}^{2+}$ can be related to transduction signal mechanisms during drought and high salinity stress. There is a known relationship between phosphatidyl metabolism and cytosolic $\mathrm{Ca}^{2+}$ in which Inositol 1,4,5-trisphosphate $\left(\mathrm{IP}_{3}\right)$ is generated by hydrolysis of the membrane phospholipid phosphatidylinositol 4,5-bisphosphate $\left(\mathrm{PIP}_{2}\right)$ by phospholipase C (PI-PLC) (Mueller-Roeber and Pical, 2002), the $\mathrm{IP}_{3}$ rapidly diffusing to other parts of the cell and prompting not only influx of extracellular $\mathrm{Ca}^{2+}$ but also its efflux from intracellular vacuoles through $\mathrm{IP}_{3}$ dependent $\mathrm{Ca}^{2+}$ channels. The pathway signalization model for the closure of guard cells mediated by abscisic acid (ABA) utilizes changes in $\mathrm{IP}_{3}$ and $\mathrm{Ca}^{2+}$ which alters the activity of $\mathrm{K}^{+}$channels leading to stomatal closure or opening (Kopka et al., 1998). It therefore seems that $\mathrm{Ca}^{2+}$ activity and phosphatidylinositol production and transfer between membranes might be indirectly related to stomata control. Thus, down-regulation of PITP expression might also be related to stomata control, although the total inactivation PITP observed in our stressed soybean plants was probably caused by a shutting-down defense mechanism.

Growth-regulator hormones, such as low concentrations auxins, can qualitatively promote, inhibit or change growth. Auxins regulate important aspects of plant growth and development, including apical dominance, tropic responses, root form, vascular tissue differentiation and cellular division. They manifest their effects by transcriptional activation of specific genes (Rouse et al., 1998), where one of the best characterized families is the Aux/ indoleacetic acid (IAA) gene family (Abel and Theologis, 1996). Most plant cell cultures need auxin for proliferation, which suggests that, under certain conditions, auxin acts as an activator of mitosis. Furthermore, the absence of auxin is known to inactivate cellular division of cultured cells from tobacco (Nicotiana tabacum) plants (Bögre and Meskiene, 2000).

The putative auxin independent growth regulator gene axi 1 seems to be directly related to cell division in plants, the regulation of this gene being mediated by various mitogenic plant growth factors using distinct signaling pathways (Walden et al., 1999). Bögre and Meskiene (2000) concluded that in tobacco cells there are independent growth-promoting pathways for cytokinin, lipochitooligosaccharide (LCO) and auxins which lead to axi 1 up regulation. The 497-bp fragment with $90 \%$ amino acid homology to axi 1 identified by us in unstressed roots indicates that the growth conditions of these roots were normal. However, under water stress, our data demonstrated a four times reduction in axi 1 putative gene expression. These results agree with the reduction in the cellular proliferative activity probably influenced by the lack of axi 1 expression in stressed conditions. According to Bögre and Meskiene (2000) stress response mechanisms are related not only to up regulation of defense genes but also to down-regulation of genes involved in normal cellular proliferation, such as the axi 1 gene. It is probable that root-cell defenses have evolved to produce cellular protective molecules (e.g., heat shock proteins, trehalose, Lea proteins, etc.) when stressed rather than normal cell metabolites (Bray, 1997; Shinozaki and Yamaguchi-Shinozaki, 2000).

Plant survival in many environments has been possible through the development of defenses and adaptive strategies because during their life cycle they encounter stresses such as drought, salinity, ultraviolet light and extreme temperatures. Tolerance or vulnerability to these abiotic stresses is very complex. Recognition of stress cues and relays signals to switch on adaptive responses that are the key steps leading to plant stress tolerance. As a result, differences in stress tolerance between cultivars or different developmental stages of a single cultivar or genotype may arise from differences in signal recognition and transduction mechanisms. The development of techniques which al- 
low plant tissue to be sampled at the moment stress is induced and signal transduction activated genes are regulated is crucial to identify differences between genotypes. However, identifying the precise moment when up or down regulation occurs is difficult, especially in tissues that normally develop bellow the soil. Methodologies that facilitate tissue sampling and simulate the conditions in natural soil should help in identifying key genes with potential for use in genetic engineering for drought tolerance. The difficulty of studying roots is well known, with gene expression studies being especially complex due difficulties in collecting roots precisely at the time molecular events happen. However, hydroponic experiments allow rapid and simple drought induction and facilitate the collection of biological material, although it is not possible to assure that this methodology precisely reproduces roots metabolism in soil under drought conditions.

Our work used hydroponic cultivation of soybean and the subsequent simulation of drought as well as cultivation in pots containing sand maintained at different levels of gravimetric humidity. We found that Axi 1, PITP and $b H L H$ were not only differentially expressed during dehydration in the hydroponics experiments but also during induced drought in the pot experiments. Although, there were differences between the two sets of experiments in the time at which up or down regulation occurred, the expression pattern of all three transcripts was very similar. In relation to the utility of hydroponic systems for the simulation of drought, it is know that response to drought depends largely in how this stress is imposed and different mechanisms are activated under moderate and progressive drought versus abrupt desiccation. However, since sampling roots under true field conditions and at the precise triggering moment is almost impossible, our hydroponics system could be used as an alternative for the rapid sampling of clean roots for gene expression analysis, since our hydroponic and sandbased pot systems produced similar results, with the hydroponic system appearing to approximate to the conditions in actual field situations.

\section{Acknowledgments}

The authors thank all those who contributed to this research. We also thank the Brazilian Higher Education Training Program (Coordenação de Aperfeiçoamento de Pessoal de Nível Superior, CAPES) and the International Foundation for Science (IFS, Grant n. C/2941-1) for financial support and the Brazilian Agricultural Research Corporation Soybean unit (Empresa Brasiliera de Pesquisa Agropecuária - Embrapa Soja) for laboratory facilities.

\section{References}

Abel S and Theologis A (1996) Early genes and auxin action. Plant Physiol 11:9-17.

Amtmann A, Bohnert HJ and Bressan RA (2005) Abiotic stress and plant genome evolution. Plant Physiol 138:127-130.
Bögre L and Meskiene I (2000) Stress the role of MAP kinases in mitogenic stimulation. Plant Mol Biol 43:705-718.

Bray EA (1997) Plant responses to water deficit. Trends Plant Sci 2:48-54.

Bray EA (2004) Genes commonly regulated by water-defict stress in Arabidopsis thaliana. J Exp Bot 55:2331-2341.

Casagrande EC, Farias JRB, Neumaier N, Oya T, Pedroso J, Martins PK, Breton MC and Nepomuceno AL (2001) Expressão gênica diferencial durante déficit hídrico em soja. Braz J Plant Physiol 12:168-184. Abstract in English.

Chen W, Provart NJ, Glazebrook J, Katagiri F, Chang H-S, Eulgem T, Mauch F, Luan S, Zou G, Whitham SA et al. (2002) Expression profile matrix of Arabidopsis transcription factor genes suggest their putative functions in response to environmental stresses. Plant Cell 14:559-574.

Chinnusamy V, Schumaker K and Zhu JK (2004) Molecular genetic perspectives on cross-talk and specificity in abiotic stress signalling in plants. J Exp Bot 395:225-236.

Cleves AE, Mcgee TP and Bankaitis VA (1991) Phospholipid transfer proteins: A biological debut. Trends Cell Biol 1:3034.

Dey PM and Harborne JD (1997) Plant Biochemistry. Academic Press, San Diego, 554 pp.

Flexas J, Bota J, Loreto F, Cornic G and Sharkey TD (2004) Diffusive and metabolic limitations to photosynthesis under drought and salinity in C3 plants. Plant Biol 6:269-279.

Göpfert H, Rossetti LA and Souza J (1993) Eventos generalizados e securidade agrícola. Ministério do Planejamento, Brasília, $78 \mathrm{pp}$.

Har PD and Cress WA (1996) Metabolic implication of stressinduced prolin accumulation in plants. Plant Growth Regul 21:79-102.

Hewitt EJ (1963) Mineral nutrition of plants in culture media. In: Stewart FC (ed) Plant Physiology. Academic Press, New York, pp 97-134.

Jaglo-Ottosen KR, Gilmour SJ, Zarka DG, Schabenberger O and Thomashow MF (1998) Arabdopisis CBF1 overexpression induces $C O R$ genes and enhances freezing tolerance. Science 280:104-106.

Kapranov P, Routt SM, Bankaitis VA, Bruijn FJ and Szczyglowski K (2001) Nodule-specific regulation of phosphatidylinositol transfer protein expression in Lotus japonicus. Plant Cell 13:1369-1382.

Kasuga M, Liu Q, Miura S, Yamaguchi-Shinozaki K and Shinozaki K (1999) Improving plant drought, salt, and freezing tolerance by gene transfer of a single stress-inducible transcription factor. Nat Biotechnol 17:287-291.

Kim YJ, Kim JE, Lee J-H, Lee MH, Jung HW, Bahk YY, Hwang BK, Hwang I and Kim WT (2004) The $V r$-PLC3 gene encodes a putative plasma membrane-localized phosphoinositide-specific phospholipase $\mathrm{C}$ whose expression is induced by abiotic stress in mung bean (Vigna radiate L.). FEBS Lett 556:127-136.

Kiribuchi K, Jikumaru Y, Kaku H, Minami E, Hasegawa M, Kodama O, Seto H, Nojiri H and Yamane H (2005) Involvement of the basic of helix-loop-helix transcription factor RERJ1 factor in wounding and drought stress responses in rice plants. Biosci Biotechnol Biochem 69:1042-1044.

Kopka J, Pical C, Gray JE and Muller-Roeber B (1998) Molecular and enzymatic characterization of three phosphoinositide- 
specific phospholipase $\mathrm{C}$ isoforms from potato. Plant Physiol 116:239-250.

Lehane JJ and Staple WJ (1965) Influence of soil texture, depth of soil moisture storage, and rainfall distribuition on wheat yields in southwestern Saskatchewan. Can J Soil Sci 45:207-219.

Lewin B (2000) Genes VII. Oxford University Press, New York, $990 \mathrm{pp}$.

Mueller-Roeber B and Pical C (2002) Inositol phospholipid metabolism in Arabidopsis. Characterized and putative isoforms of inositol phospholipids kinase and phosphoinositide-specific phospholipase C. Plant Physiol 130:22-46.

Nepomuceno AL, Oosterhuis D and Stewart JM (1998) Physiological responses of cotton leaves and roots to water deficit induced by polyethylene glycol. Environ Exp Bot 40:29-41.

Nepomuceno AL, Oosterhuis D, Stewart JM, Turley R, Neumaier $\mathrm{N}$ and Farias JRB (2002) Expression of heat shock protein and trehalose-6-phosphate synthase homologues induced during water deficit in cotton. Braz J Plant Physiol 14:11-20.

Ribas-Carbo M, Taylor NL, Giles L, Busquets S, Finnegan PM, Day DA, Lambers H, Medrano H, Berry JA and Flexas J (2005) Effects of water stress on respiration in soybean leaves. Plant Physiol 139:466-473.

Rouse D, Marckay P, Stirnberg P, Estelle M and Leyser O (1998) Changes in auxin response from mutation in on AUX/IAA gene. Science 270:1371-1373.

Shinozaki K and Yamaguchi-Shinozaki K (1997) Gene expression and signal transduction in water-stress response. Plant Physiol 115:327-334.

Shinozaki K and Yamaguchi-Shinozaki K (1999) Molecular responses to drought stress. In: Shinozaki K and YamaguchiShinozaki K (eds) Cold, Drougth, Heat and Salt Stress in Higher Plants. R.G. Landes Company, Austin, pp 11-28.
Shinozaki K and Yamaguchi-Shinozaki K (2000) Molecular responses to dehydration and low temperature: Differences and cross-talk between two stress signaling pathways. Curr Opin Plant Biol 3:217-223.

Shinozaki K and Yamaguchi-Shinozaki K (2007) Gene networks involved in drought stress response and tolerance J Exp Bot 58:221-227.

Shinozaki K, Yamaguchi-Shinozaki K and Seki M (2003) Regulatory network of gene expression in the drought and cold stress responses. Curr Opin Plant Biol 6:410-417.

Somerville C and Koornneef M (2002) A fortunate choice: The history of Arabidopsis as a model plant. Nat Rev Genet 3:883-889.

Song P, Yamamoto E and Allen RD (1995) Improved procedure for differential display of transcripts from cotton tissues. Plant Mol Biol Rep 13:174-181.

Walden AR, Walter C and Gardner RC (1999) Genes expressed in Pinus radiata male cones include homologs to antherspecific and pathogenesis response genes. Plant Physiol 121:1103-1116.

Wirtz KWA (1991) Phospholipid transfer proteins. Annu Rev Biochem 60:73-99.

Yamaguchi-Shinozaki K, Kasuga M, Liu Q, Nakashima K, Sakuma Y, Abe H, Shinwari ZK, Seki M and Shinozaki K (2002) Biological mechanisms of drought stress response. JIRCAS Working Rep 23:1-8.

Zhang JZ, Creelman RA and Zhu J-K (2004) From laboratory to field. Using information from Arabidopsis to Engineer Salt, cold, and drought tolerance in crops. Plant Physiol 135:1-7. Associate Editor: Márcio de Castro Silva Filho

License information: This is an open-access article distributed under the terms of the Creative Commons Attribution License, which permits unrestricted use, distribution, and reproduction in any medium, provided the original work is properly cited. 